http://dx.doi.org/10.18778/1508-1117.26.02

Krystyna Krawiec-Złotkowska

\title{
BAROKOWY HORTUS LUDI W PERSPEKTYWIE GEOPOETYKI (NA WYBRANYCH PRZYKLADACH LITERACKICH)
}

Zarys treści Artykuł ukazuje barokowy hortus ludi (ogród zabaw) w perspektywie geopoetyki. Przedmiotem eksploracji są wybrane utwory poetów XVII wieku, na podstawie których badane zjawisko zostało poddane refleksji. Wykazano, na ile rzeczywiste miejsca mogły inspirować autorów opisujących szlacheckie bądź magnackie wirydarze, a z drugiej strony podjęto próbę określenia, w jakim stopniu kreacja literacka buduje miejsca poddane deskrypcji u potencjalnego odbiorcy dzieła literackiego (czytelnika). W wyniku analizy stwierdzono, że opisy barokowych hortus ludi to kreacje miejsc przetworzone w umyśle poety, odznaczające się aspektem malarskości, który może inspirować nie tylko architektów krajobrazu, ale również malarzy i innych artystów.

W artykule uwzględniono także genezę barokowych ogrodów zabaw i cechy charakterystyczne parkowo-ogrodowych założeń począwszy od średniowiecza po barok. Obecny w poezji XVII wieku hortus ludi ukazano w nowym, geopoetycznym ujęciu.

Słowa kluczowe Barok, poezja, kultura, ogród, hortus ludi, Arkadia, topos, przestrzeń, geopoetyka, interakcje geograficzno-literackie.

\section{Wprowadzenie}

Celem artykułu jest przedstawienie przestrzeni ogrodu przez historyków sztuki i architektów krajobrazu określanego jako hortus ludi. Ogród zabaw interesuje autorkę niniejszego studium w kontekście historycznoliterackim oraz w wymiarze oddziaływania kreacji literackich na wyobrażenia o tego typu przestrzeniach na potencjalnych odbiorców tekstów poetyckich. Będą to zatem refleksje z obszaru geopoetyki, którą Elżbieta Rybicka rozumie jako orientację badawczą, zmierzającą w stronę kompleksowego, wieloaspektowego - choć niecałościowego - projektu analizowania i interpretowania interakcji i cyrkulacji, jakie zachodzą pomiędzy 
twórczością literacką i praktykami kulturowymi z nią związanymi a przestrzenią geograficzną (Rybicka 2014, s. 92 i nn.). Uczona zauważa, że: „Podstawowym zadaniem geopoetyki nie jest wyłącznie badanie reprezentacji, tropienie śladów geograficznych w literaturze, ale stawianie pytań o to, co twórczość literacka czyni - w ramach poetyki i poiesis - z owym miejscem czy obszarem. Celem geopoetyki nie będzie zatem „mapowanie” literackich światów, lecz pytanie o to, co dzieje się pomiędzy, w międzyprzestrzeni: pomiędzy „geo” a poetyką, pomiędzy przestrzenią geograficzną a literaturą" (Rybicka 2014, s. 34).

Adekwatnie do powyższego założenia geopoetyka kładzie nacisk na dwukierunkowy proces interakcji - z jednej strony na podmiotowe doświadczanie miejsc oraz ich pojetyczne ${ }^{1}$ tworzenie, $\mathrm{z}$ drugiej strony na aktywną rolę miejsc w owym doświadczeniu. Sfera „geo” - jak twierdzi E. Rybicka (2014, s. 93) - nie jest bowiem jedynie przedmiotem i efektem literackich i kulturowych praktyk pojetycznych, ale może również być - $\mathrm{i}$ to w takim samym stopniu jak poiesis - siłą sprawczą. W konsekwencji relacja pomiędzy przestrzenią geograficzną a twórczością literacką oparta jest na wzajemnej zależności, ma charakter chiazmatyczny; inaczej rzecz ujmując geopoetyka zakłada pojetyczność geografii i geograficzność twórczości literackiej.

Problematyka pojetyczności geografii i pojetycznego tworzenia miejsc wydawać się może mało precyzyjna i wymaga pewnego dopowiedzenia. Otóż, przyjęcie powyższej tezy jest wynikiem współczesnych koncepcji miejsc, które są tworzone przez różnorodne praktyki kulturowe (np. sztukę, literaturę, film) i pozostają w bezpośrednim związku z praktykami codziennymi (zamieszkiwaniem na jakimś konkretnym obszarze, podróżowaniem lub przemieszczaniem się, opuszczaniem terenu oraz jego sensualnym postrzeganiem). Musimy być świadomi, że pojetyczne tworzenie miejsc jest procesem, wydarzeniem, skutkiem jakiegoś układu sił zewnętrznych. Miejsca te nie są takimi samymi wytworami jak produkty zamknięte i sfinalizowane (np. jakieś wyprodukowane gotowe przedmioty), gdyż są otwarte na czas, inne loci, a przede wszystkim na zróżnicowaną - bo tworzoną w heterogonicznych praktykach kulturowych - semantykę.

Pojetyczność i sprawczość miejsc również jest kwestią problematyczną, niemniej tak w badaniach literackich, jak i geograficznych czy socjologicznych można w tej materii zaobserwować dość zbliżone stanowiska. I tak np. według opinii Franca Moretti, przestrzeni geograficznej nie można postrzegać jak pojemnika, w którym „zdarza się" historia kulturowa, lecz jako aktywną siłę, która wkracza w obszar literatury i kształtuje go w głęboki sposób (Moretti 1998, s. 3). Michel Collot jest zdania, że miejsca mają swoją poetykę (le poétique) rozumianą jako wywoływanie emocji oraz aktywizowanie wyobraźni (Collot 2008, s. 312). William John Thomas Mitchell twierdzi, że krajobraz nie jest wyłącznie przed-

${ }^{1}$ Pojetyka to $\mathrm{z}$ gr. umiejętność sprawcza, zdolność tworzenia i podstawa działania (Arystoteles). 
miotem obserwacji lub tekstem do czytania, lecz procesem, za pomocą którego są kształtowane jednostkowe i społeczne tożsamości; uczony ten nie pyta o to, czym krajobraz jest lub co znaczy, lecz stawia pytania o to, co krajobraz czyni i w jaki sposób działa jako kulturowa praktyka (Mitchell 2002, s. 312). Bruno Latour z kolei sprawczość miejsc ujmuje w sieci interakcji (Latour 2010, s. 284 287). Podobne stanowisko zajmuje geograf Robert David Sack, który wskazuje, że miejsca będące wytworem sił społecznych, natury i znaczeń w relacji z człowiekiem pełnią rolę czynnika sprawczego (Sack 1997, s. 13-14). Czynnościowe i sprawcze interpretowanie loci i przestrzeni jest również podkreślane $\mathrm{w}$ badaniach performatywnych (Fischer-Lichte 2008, s. 174-194)2.

Uwzględniając zarysowaną powyżej relację pomiędzy sferą „geo” a poiesis, między przestrzenią geograficzną a twórczością literacką i nawiązując do historii tychże pojęć, wyróżnia się cztery główne aspekty geopoetyki jako orientacji badawczej: poetologiczną, geograficzną, antropologiczną i performatywną.

Geograficzny charakter geopoetyki proponuje terminologię kojarzoną przede wszystkim z geografią. Badania zorientowane na tę dyscyplinę będą wykorzystywały takie kategorie, jak: mapa, miejsce, obszar, krajobraz, terytorium, region, granice i pogranicza (rozumiane przestrzennie), centrum i peryferie, a także geografia wyobrażona. Kategorie te w ujęciu geopoetycznym mogą być eksplorowane $\mathrm{z}$ perspektywy ich znaczenia dla literatury i literaturoznawstwa (Rybicka 2014, s. 106-107). Orientacja antropologiczna geopoetyki jest natomiast ukierunkowana na badanie relacji, jakie zachodzą pomiędzy przestrzenią geograficzną a podmiotem funkcjonującym $\mathrm{w}$ tej przestrzeni. W tym wymiarze najistotniejsze znaczenie mają sensualny empiryzm i reakcje emocjonalne, które prowadzą do: ,...) literackiej geografii sensorycznej, geografii emocji i topografii emotywnych. Istotnym problemem będzie także zagadnienie geograficznych ram pamięci jednostkowej, które pozwala spojrzeć w nowym świetle na autobiografię i biografię" (Rybicka 2014, s. 107).

Performatywny aspekt geopoetyki dotyczy działania i praktyk zainicjowanych w realnym świecie przez tekst literacki; literatura w tej sytuacji pełni rolę inspirującą i sprawczą, pod jej wpływem zmienia się rzeczywistość, a więc i przestrzeń geograficzna - tak w sensie materialnym, jak i mentalnym. Performatywny wymiar geopoetyki może unaocznić przykład Rydlówki (dworku w Bronowicach, siedziby Muzeum Młodej Polski), która jako instytucja kultury istnieje w przestrzeni publicznej za sprawą Wesela Stanisława Wyspiańskiego i inne tego typu miejsca, które pojawiły się w rzeczywistości w wyniku oddziaływania literatury, budującej materialny i niematerialny majątek kulturowy różnych miejsc i regionów. To ekonomiczne i symboliczne dziedzictwo jest obecnie utrwalane w przewodnikach i promowane w formie tzw. „turystyki literackiej”. Ta swoista „pro-

${ }^{2}$ Na temat badań F. Moretti, M. Collota, W.J.T. Mitchella, B. Latour'a, R.D. Sack'a oraz E. Fischer-Lichte'a porównaj: E. Rybicka (2014, s. 94 i nn.). 
mocja" jednocześnie uzmysławia, że niektórych miejsc rzeczywistych nie można oddzielać od ich kreacji tekstowych, gdyż to właśnie one - adekwatnie do reguł performatywnych - modyfikują i tworzą na nowo ich wyobrażoną geografię. Poza tym literatura może budować silny związek z jakimś miejscem, a na mapach rzeczywistych i mentalnych wskazywać punkty orientacyjne oraz generować szablony interpretacyjne, czy też odkrywać miejsca z przeszłości, zapomniane lub wyparte ze świadomości (Rybicka 2014, s. 107-111).

Orientacja poetologiczna jest natomiast związana z poetyką jako dziedziną badań literackich, ale skoncentrowaną na elementach geograficznych; tym samym nie jest to poetyka w tradycyjnym jej znaczeniu (Balbus 1995, s. 7-31), ale poetologia (Kuźma 1995, s. 41-52) ujęta w ramy zwrotu topograficznego - rozumianego jako odmiana zwrotu przestrzennego ${ }^{3}$ - odnoszącego się do obszaru graphein, czyli dziedzin przyznających największe znacznie językowemu (i jednocześnie obrazowemu, bo gr. czasownik graphein znaczy: pisać lub rysować) ujęciu przestrzeni ${ }^{4}$. Język ma ogromne znaczenie dla geopoetyki w kontekście tradycji retorycznej (,topotropografia” stanowi punkt wyjścia do badania roli tropów retorycznych w literackich topografiach oraz mitotwórczego znaczenia metaforyki przestrzennej), toponomastyki jako części onomastyki literackiej (obecność lub nieobecność toponimów w geopoetyce jest znacząca i tak pierwszy, jak i drugi wariant wymaga interpretacji; w roli tropów toponomastycznych mieszczą się również geograficzne nazwy własne), wreszcie ze względu na właściwości języka, w którym mogą występować regionalizmy lub stylizacje lingwistyczne,

${ }^{3}$ Zwrot przestrzenny jest ruchem obecnym w wielu dyscyplinach naukowych - przykładem socjologia, nauki polityczne, antropologia, filozofia, historia i historia sztuki, badania kulturowe i literackie - od ostatniej dekady XX wieku. Został zapoczątkowany w końcu lat 60. ubiegłego stulecia radykalnymi przemyśleniami Henriego Lefebver'a (twórcy teorii o społecznym wytwarzaniu przestrzeni), Michela Foucalta (badającego heterotopie), Gilles’a Deleuz'a i Felixa Guattari (zajmujących się myślą nomadyczną oraz dei reterytorializacją), Michela de Corteau (eksplorującego praktyki przestrzenne) oraz Marca Augé (analizującego nie-miejsca i przestrzenie tranzytowe). O genealogii zwrotu przestrzennego pisali m.in.: B. Warf, S. Arias (2009), E.W. Soja (2009), K. Schlögel (2009, s. 56-68), D. Bachmann-Medick (2012).

${ }^{4} \mathrm{~W}$ ramach reorientacji studiów historycznoliterackich określenie ,,Zwrot topograficzny” wydaje się bardziej wskazane niż ,zwrot przestrzenny”, ponieważ „,zwrot topograficzny posiada (...) zdecydowanie większy i atrakcyjniejszy potencjał semantyczny dla badań literackich. Etymologicznie topografia jako topos graphos - opis przestrzeni - ma solidniejsze uzasadnienie na gruncie literaturoznawstwa, nie tylko ze względu na bogatą i długą tradycję retoryczną. We współczesnym krajobrazie myślowym topografia współgra bowiem z przeświadczeniem o literackim i kulturowym wytwarzaniu przestrzeni. Doskonale rezonuje też z innymi rodzinnymi pojęciami - heterotopiami i topotropografią, toponimią i topologią, atopią, utopią i dystopią czy wreszcie mnemotoposami” (Rybicka 2014, s. 33). W tym kontekście zobacz też: J.H. Miller (1995), Z. Dziuban (2008). 
ujawniające na przykład różnice między normatywnym językiem narodowym a językami nacechowanymi lokalnie i terytorialnie (Rybicka 2014, s. 95-97).

Poetologiczne ukierunkowanie geopoetyki umożliwia również badania w kontekście genologii gatunków literackich, które pojawiając się w historii były związane ze specyfiką jakiegoś miejsca lub konkretnego obszaru geograficznego; przykładem mogą być tu legendy i podania powiązane z realnymi miejscowościami (np. O Wandzie, co nie chciała Niemca, czy o Lechu, Czechu i Rusie) poematy opisowe i krajoznawcze (np. Powazki lub Sofiówka Stanisława Trembeckiego), obrazy i obrazki topograficzne, kreowane przechadzki lub dzienniki z podróży czy gatunki proweniencji lokalnej, jak dumki, dumy, kasydy, haiku - ich differentia specifica ułatwia nie tylko analizę, lecz również określenie, w jaki sposób i w jakim zakresie określone formy literackie wchodzą w relacje z geografią (np. jakie są związki poematu opisowego z przedmiotem opisu czy też, jak wygląda cyrkulacja i modyfikacja gatunków specyficznych dla określonych terenów i kultur).

Problematyka genologiczna koresponduje także z topografią pojmowaną jako technika opisu miejsc realnych i wyimaginowanych, której korzenie - i tradycja z podziałem na topografię i topotezję, opis unaoczniający, hypotypozy, ekfrazy, etopeje i prozopografie - sięgają retoryki antycznej. We współczesnej humanistyce - pod wpływem badań zachodnioeuropejskich - od kilku dekad stały się niezwykle modne zwłaszcza ekfrazy (z gr. ékphrasis - szczegółowy opis). Terminu tego używa się w kontekście wszelkiego rodzaju literackich przedstawień dzieł plastycznych i architektonicznych (przedmiotów artystycznych, obrazów, rzeźb, budowli itp.). Uczeni badający poetyckie i prozatorskie ekfrazy poszukują pokrewieństw tekstów literackich ze sztukami plastycznymi ${ }^{5}$. Poza tym w ścisłym związku z ekfrazami pozostają hypotypozy - czyli opisy tak sugestywne, że niemal namacalne. Różnica między tymi pojęciami polega na tym, że deskrypcja w hypotypozie - w przeciwieństwie do ékphrasis - nie dotyczy jakiegoś określonego dzieła sztuki, ale kreuje obraz wyobrażony i wymusza na czytelniku konieczność ustalenia kryteriów, które umożliwią wskazanie w tekście wyznaczników malarskości.

Przez pryzmat geopoetyki można również analizować postać literacką, która - jako realizacja określonej koncepcji antropologicznej - jest kreowana na boha-

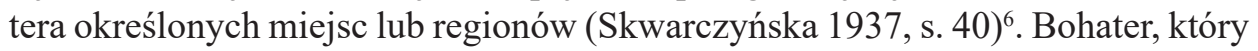
należy do świata przedstawionego utworu jest motywowany kulturowo, a taka konstrukcja postaci pozwala na refleksję o zależnościach geograficznych typu: za-

${ }^{5} \mathrm{~W}$ antyku ekfrazą określano zarówno kategorię gatunkową, jak i oratorską figurę, która polegała na unaoczniającym przedstawieniu jakiegoś przedmiotu lub zjawiska przestrzennego; mogła ona dotyczyć tak rzeczywistych, jak i wymyślonych obiektów.

${ }^{6}$ Stefania Skwarczyńska (1937, s. 40) pisała, że autor „lokalizując akcję lokalizuje (...) psychikę bohaterów. Chce z nich zrobić ludzi pewnych okolic, o ile (...) nie chce świadomie ulepić z nich typów pozaregionalnych". 
korzenienia na danym terenie, osiadłości lub nomadyzmu, wyjazdów i powrotów, czyli wszelkiego rodzaju migracji. Przestrzenne i geograficzne atrybuty bohatera umożliwiają określenie punktu jego widzenia i usytuowanie go w określonej konfiguracji podmiotowej (Rybicka 2014, s. 100).

Osobnym zagadnieniem w perspektywie geopoetyki jest określenie miejsca czytelnika i percepcji tekstu literackiego. Na lekturę, której fabuła rozwija się w jakimś konkretnym obszarze, oddziałuje znajomość terenu poddanego deskrypcji (Skwarczyńska 1937, s. 46 i nn.). Miejsca znane mogą konotować określone - złe lub dobre - skojarzenia. Inaczej rzecz ujmując, wiedza o rzeczywistym, geograficznym usytuowaniu przestrzeni może utrudniać, a czasami wręcz uniemożliwiać immanentny odbiór dzieła. W tym miejscu warto się zastanowić, w jakim stopniu geograficzny kontekst wpływa na lekturę i wyobraźnię czytelniczą - wyobraźnia osób znających opisywany obszar będzie zdeterminowana mimesis, natomiast imaginacja czytelników nieznających szczegółów topograficznych prezentowanej przestrzeni będzie wolna i nieskrępowana rzeczywistym obrazem danego loci.

Dzięki zastosowaniu przywołanych wyżej odmiennych perspektyw badawczych można skutecznie analizować zasadniczy przedmiot zainteresowania geopoetyki - czyli interferencje zachodzące między tekstami literackimi a przestrzenią geograficzną (Rybicka 2014, s. 94 i nn.). Badacze zróżnicowanych obszarów nauki podzielają consensus na temat statusu przestrzeni, którą traktują jako „,społeczny konstrukt istotny do rozumienia zróżnicowanych historii ludzkich podmiotów i do wytwarzania zjawisk kulturowych" (Warf, Arias 2009, s. 1; Soja 2009, passim; Schlögel 2009, passim; Bachmann-Medick 2012, passim). Takie założenie stanowi ramę dla zwrotu topograficznego i prowadzi w różne obszary pisarstwa i literackich analiz; przykładem mogą być tu choćby geografie wyobrażone reinterpretowane $\mathrm{i}$ badane $\mathrm{w}$ ujęciach postkolonialnym, etnicznym czy kształtującym tożsamość narodową - opartą na literackich obrazach ideologicznych i rozmieszczeniach przestrzennych (związanych z przekonaniem, że literatura kreuje i transmituje narodowe krajobrazy i ideologiczne loci, czego wymiernym przykładem jest dziewiętnastowieczna narodowa topika przestrzenna wykreowana w literaturze polskiej na opozycji miasto-wieś (Ihnatowicz 1997; Rybicka 2003); źródła tej opozycji tkwią w renesansowym toposie „wsi spokojnej, wsi wesołej” (Krzewińska 1979, passim; Karpiński 1983, passim; Zaleski 2007, passim) antycznej proweniencji ${ }^{7}$, wykreowanym i utrwalonym w poezji polskiej przez Jana Kochanowskiego i innych twórców, którzy czerpali inspiracje z jego Pieśni świętojańskiej o Sobótce.

\footnotetext{
${ }^{7}$ Renesansowy topos „wsi spokojnej, wsi wesołej” wyrasta z poezji Wergiliusza (zwłaszcza z wierszy bukolicznych i Georgik - dosyć szczegółowy passus o ogrodach w Księdze IV, w. 118-148) oraz Horacego (tu przede wszystkim epoda II, Beatus ille...). Zob. J. Kochanowski (1972, s. 301-318), Wergiliusz (1953), Horacy (1971, s. 172-175).
} 
Z toposem „wsi spokojnej” wiąże się topos ogrodu jako miejsca szczęśliwego, substytutu niebiańskiego raju w przestrzeni ziemskiej (Delumeau 1994, passim; Krawiec-Złotkowska 2009, s. 83-103). Ogród w kulturze staropolskiej stanowił naturalny komponent szlacheckich gospodarstw (Krawiec-Złotkowska 2007, s. 221-230, 2008b, 2008c) i magnackich bądź królewskich rezydencji (KrawiecZłotkowska 2008a, s. 30-38; Ciołek 2009, passim; Majdecki 2009, passim). Architektonicznym rozwiązaniom przestrzennym sztuki ogrodowej zawsze towarzyszyła poezja o ogrodach - zarówno w wymiarze mimetycznym, jak i symbolicznym.

\section{Barokowe hortus ludi w ujęciu geopoetycznym}

W baroku - epoce naznaczonej piętnem Vanitas, okresie pogrążonym w cieniu Marsa i Bellony - znaczenie ogrodów, które gwarantowały inną perspektywę postrzegania świata zewnętrznego, było szczególne i wyjątkowe. Z tego też względu przedmiotem badawczej eksploracji w niniejszym studium będą utwory, które wyszły spod pióra poetów żyjących i tworzących w XVII wieku; te, które - jakby na przekór czasom i brakowi stałych egzystencjalnych fundamentów - ewokują ogrody dostarczające rozkoszy duchowej i cielesnej, czyli barokowe hortus ludi stanowiące wśród założeń ogrodowo-pałacowych interesujące zjawisko socjologiczno-kulturowe.

Ambicją autorki nie jest oczywiście szczegółowa egzemplifikacja wszystkich tego typu ogrodowych „zdarzeń”, jakie w niezwykle bogatej poezji barokowej można wskazać, lecz analiza wybranych utworów literackich, które w jakimś stopniu - z pewnością niewyczerpującym problemu - wizualizują interesujące nas zjawisko, kształtują u odbiorców realistyczny lub skonwencjonalizowany obraz prezentowanych przestrzeni, wywołują pozytywne (lub czasami negatywne) skojarzenia i budzą zróżnicowane emocje. Badaniom zostaną poddane teksty poetyckie: Pieśń XXXI z Księgi I, Gniazdo ojczyste do moich M.M. P.P. braciej i Pieśń XXIII, Rozjezne pożegnanie z ojczystym Gajem dnia 19 maja 1663 z Ksiag III Wespazjana Kochowskiego (Kochowski 1991, s. 53-56, 126-129), Waleta włoszczonowska Kaspra Miaskowskiego (Miaskowski 1988, s. 187-189) oraz Rozmowy Artaksesa i Ewandra Stanisława Herakliusza Lubomirskiego (Lubomirski 2006).

\section{Tradycja barokowych ogrodów zabaw}

Siedemnastowieczne ogrody zabaw mają długą tradycję. Sięga ona swymi korzeniami średniowiecznych założeń ogrodowych. Ówczesne wirydarze organizowano głównie wewnątrz zamków. Były one małe i ciasne. Pod oknami komnat budowano tzw. ogród zamknięty, którym opiekowały się kobiety. Uprawiano 
w nim aromatyczne kwiaty i zioła. Wszystko uzupełniały liczne ścieżki, fontanny oraz ławeczki. Najczęściej sadzono w nich róże (w ten sposób zaistniały tzw. rozaria, czyli ogrody różane). Miejsca te były ściśle ogrodzone, miały charakter zamknięty. Pozostawały w opozycji do otoczenia. Były swoistą oazą piękna i dobra kontrastującą z resztą świata. W ich obrębie można wyróżnić wirydarze zamkowe o charakterze ozdobnym oraz ich wariant zaadaptowany w klasztorach - hortus conclusus, czyli ogrody służące kontemplacji, które wykorzystywano jako tło przedstawień religijnych, przede wszystkim związanych ze sceną Zwiastowania NMP (fot. 1). Obok nich istniały w średniowieczu również założenia ozdobno-użytkowe, czyli zielniki oraz typowo użytkowe w postaci sadów, winnic, chmielników i warzywników. Wszelkim rozrywkom oddawano się natomiast w tzw. ogrodach zabaw, które najczęściej były łąką otoczoną drzewami i kwiatami (fot. 2). Tu najczęściej pojawiały się źródła i fontanny (będące alegorią źródła życia) oraz baseny; żywopłoty formowano w figury geometryczne. Częścią zamkowych wirydarzy były również zwierzyńce, w których trzymano niedźwiedzie, żubry i łosie oraz menażerie zaopatrzone w egzotyczne okazy, takie jak np. lwy czy lamparty. Bardzo częstym motywem ogrodu średniowiecznego był też labirynt, który funkcjonował w kulturze jako alegoria zagmatwanych losów ludzkich i ułatwiał wyrażanie emocji zdeterminowanych dualistycznym postrzeganiem świata (Ciołek 2009, s. 163-166; Impelluso 2009, passim; Czapiga 2013, passim).

Tradycję średniowieczną stosowaną w budowie ogrodów kontynuowano w renesansie. Odrodzeniowy ogród miał nadal spełniać funkcję utylitarną. Jednak obok średniowiecznych rodzimych inspiracji pojawiły się tendencje nowe, napływające do Polski z południowej i zachodniej Europy, niemające związku z czysto użytkową formą ówczesnych dziardynów. I tak w połowie XVI wieku w założeniach ogrodowych zaczęto stosować idee włoskich artystów, zwłaszcza Albertiego, Bramantego oraz Rafaela, wprowadzano symetrię, umieszczano budowlę centralną oraz skromne, pojedyncze motywy ujęte w gotyckie ramy. Od tego czasu na oznaczenie ozdobnego ogrodu przyjęła się w Polsce nazwa ogrody włoskie. W organizowaniu przestrzeni odrodzeniowych ogrodów posługiwano się także tzw. manierą holenderską, a mianowicie wprowadzano: złote odlewy rzeźb, kunsztowne strzyżenie drzew i krzewów (figury ludzkie, jak i geometryczne) oraz fosy i kanały wodne. W okresie tym nie zabrakło również maniery starofrancuskiej przejawiającej się w wyeksponowaniu jednej osi, przeciwstawianiu płaszczyzn dużych parterów i wodnych zwierciadeł zwartym, wysokim bryłom zieleni (Ciołek 2009, s. 163-165).

Największą popularnością w dobie odrodzenia cieszył się ogród kwaterowy, w którym obowiązywała zasada styczności wnętrz oraz wielopoziomowe tarasy. Najpowszechniejszymi formami tych ogrodów były wirydarze w kształcie czworoboku, o parterze złożonym z regularnych kwater (taki układ ma m.in. ogród w Jędrzejowie), a także sady o nieregularnych czworobocznych ramach 


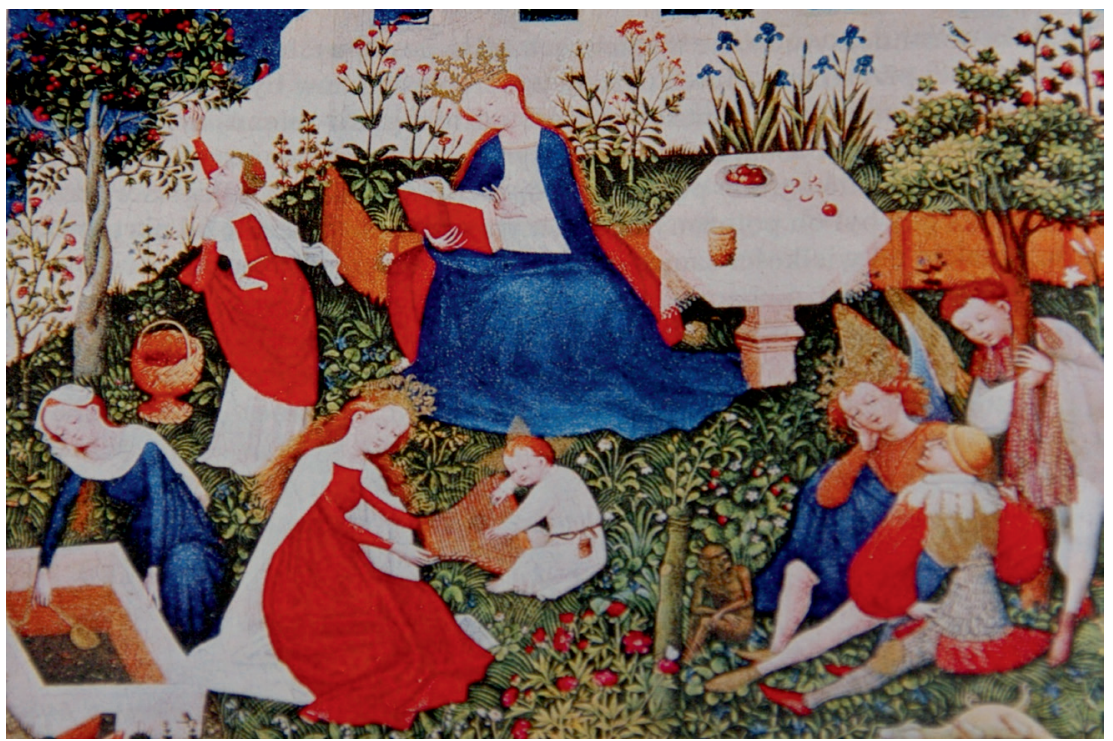

Fot. 1. Madonna w ogrodzie - hortus conclusus, obok którego wykształcił się hortus ludi. Widok małego ogrodu ozdobnego (ok. 1410 r. - Mistrz Górnoreński, Stadelsches Kunstinstitut, Frankfurt nad Menem)

Źródło: https://pl.wikipedia.org/wiki/Rajski_ogr\%C3\%B3d

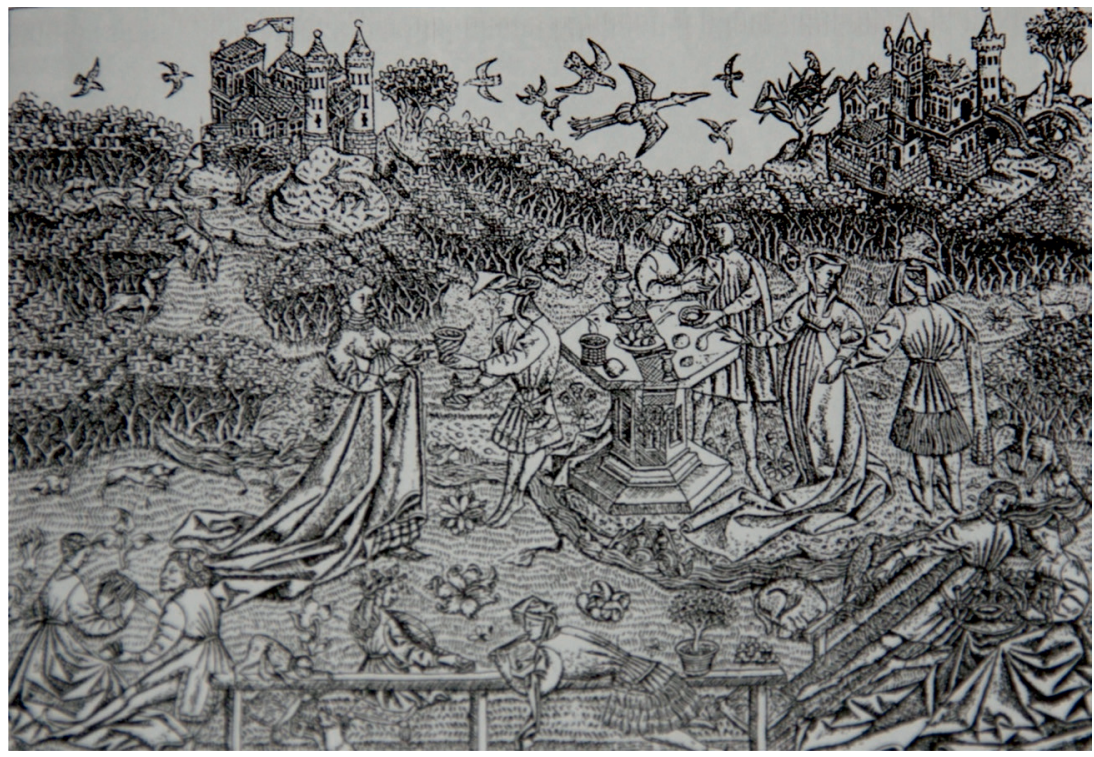

Fot. 2. Widok dużego „ogrodu miłości” (poł. XV w.)

Zamkowy ogród zabawowy - hortus ludi

Źródło: http://www.historiasztuki.com.pl/strony/007-01-00-HISTORIA-OGRODOW.html 
i nieakcentowanych ulicach (przykładem może być ogród klasztorny bernardynów krakowskich oraz zamkowy w Wiśniczu), winnice o wielu wnętrzach, otwarte ku południu swą dłuższą stroną i ograniczone trzema ścianami (np. na Bielanach) oraz ogrody szachownicowe stanowiące połączenie trzech wyżej wymienionych typów (w Łowiczu i Zamościu). Ważnym elementem renesansowych ogrodów były loggie wiążące wnętrze domu z ogrodem, a także altany i pergole oraz zwierzyńce i liczne detale wodne, jak np. fontanny, które uległy poszerzeniu i obniżeniu, czy kaskady (Ciołek 2009, s. 166 i nn.).

Renesansowe ogrody były też nieodłącznym elementem wiejskich posiadłości. Były to miejsca sielskie i ustronne, gdzie stawiano na piękno krajobrazu. Niezależnie od ich usytuowania przestrzennego postrzegano je i wartościowano - adekwatnie do wzorców przejętych z antyku - jako loci amoeni, czyli miejsce miłe i przyjazne, stwarzające warunki dla odpoczynku i twórczego myślenia. Przestrzeń pięknego ogrodu sprzyjała zresztą nie tylko wytchnieniu i natchnieniu, ale i dobrej zabawie - ogród stał się miejscem uciech i wyszukanych rozrywek, którym towarzyszyło rozluźnienie obyczajów. Z czasem, wraz z kontrreformacją, ogrody stały się miejscem kontemplacji - przemiana ta (oczywiście nie radykalna i niezupełnie nowatorska, bo już w średniowieczu istniały hortus conclusus) była spowodowana czynnikiem moralizatorskim, związanym z refleksją religijną.

Siedemnastowieczni ogrodnicy marzyli natomiast, aby naturę przemienić w sztukę. Klasyczny ogród miał stać się: „modelem harmonijnego universum” (Ciołek 2009, s. 166). Jednak, aby porządek ogrodu mógł odzwierciedlać porządek świata, musiał nad nim zapanować człowiek. Toteż w ogrodach - i to na nieznaną wcześniej skalę - zaczęto umieszczać fontanny, baseny i altany, budowano również groty, pustelnie i świątynie. Nie zabrakło także pawilonów do gier i zabaw. Odchodzono od sadzenia roślinności, gdyż była ona nietrwała, uzależniona od warunków klimatycznych, które często nie sprzyjały uprawie delikatnych roślin, czy rzadko spotykanych, wymagających gatunków. Możliwość przetrwania, mimo zmieniającej się pogody i pór roku, miały jedynie artefakty, czyli wytwory rąk ludzkich (np. rzeźby).

Kryterium harmonii spełniały tzw. ogrody francuskie. W ogrodach tego typu przeważała symetria, a natura stawała się sztuką i odwrotnie. Twórcą tego typu ogrodów był siedemnastowieczny francuski architekt krajobrazu André Le Nôtre, który na polecenie Ludwika XIV (we współpracy z architektem Louisem Le Vau i odpowiedzialnym za wystrój Charlesem Le Brun) zaprojektował i rozbudował ogrody Wersalu ${ }^{8}$ (fot. 3). Le Nôtre korzystał z pomysłów holenderskich

\footnotetext{
${ }^{8}$ Warto w tym miejscu przypomnieć, że przebudowę Wersalu i założenie ogrodów Ludwika XIV poprzedziło w XVII wieku powstanie zespołu pałacowo-ogrodowego Vaux-le-Vicomte dla Nicolasa Fouqueta, wysokiego urzędnika państwowego, od 1653 roku ministra finansów króla Ludwika XIV (fot. 4). Budowa nowej posiadłości Fouqueta rozpoczęła się w roku 1656, a koordynowało ją trzech artystów, którzy tutaj po raz
} 


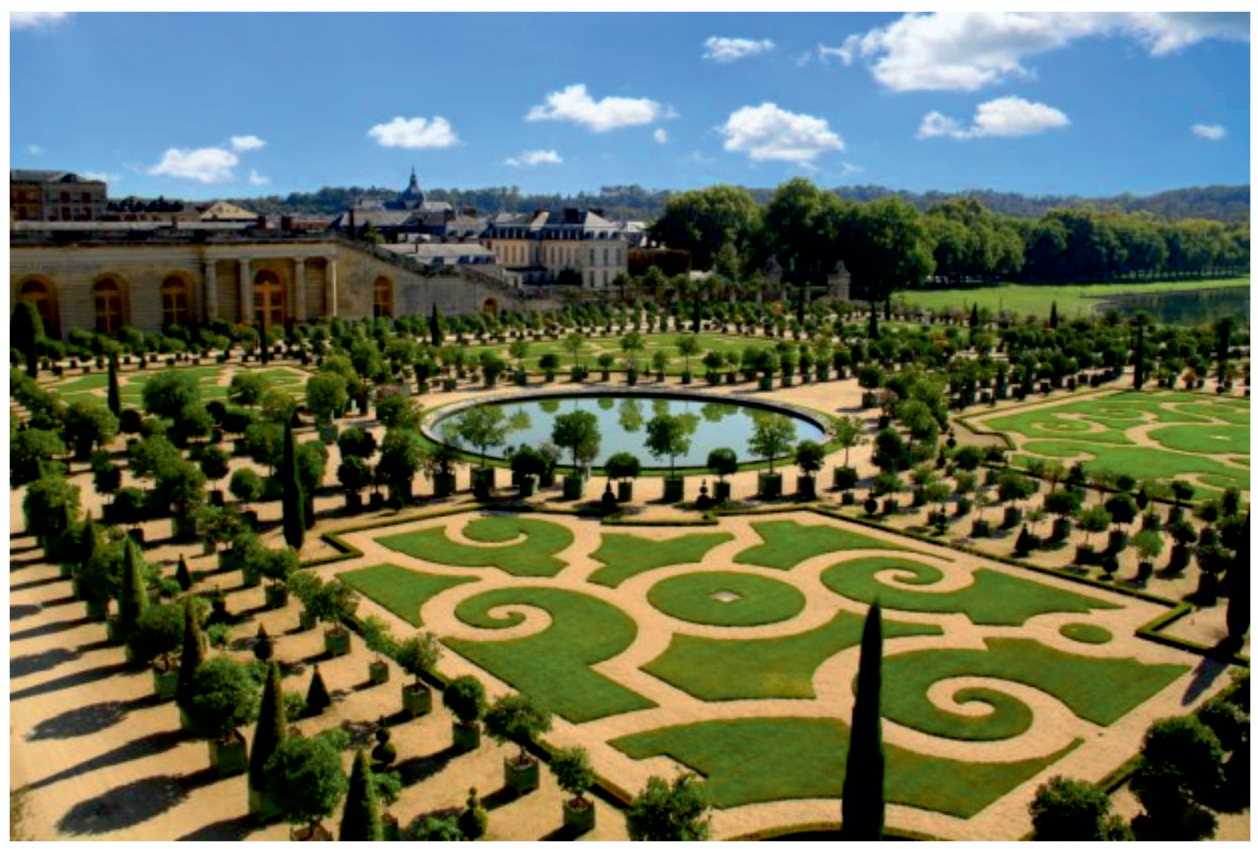

Fot. 3. Fragment ogrodów w Wersalu, stan współczesny

Źródło: http://podroze.gazeta.pl/podroze/51,114158,12037151.html?i=1

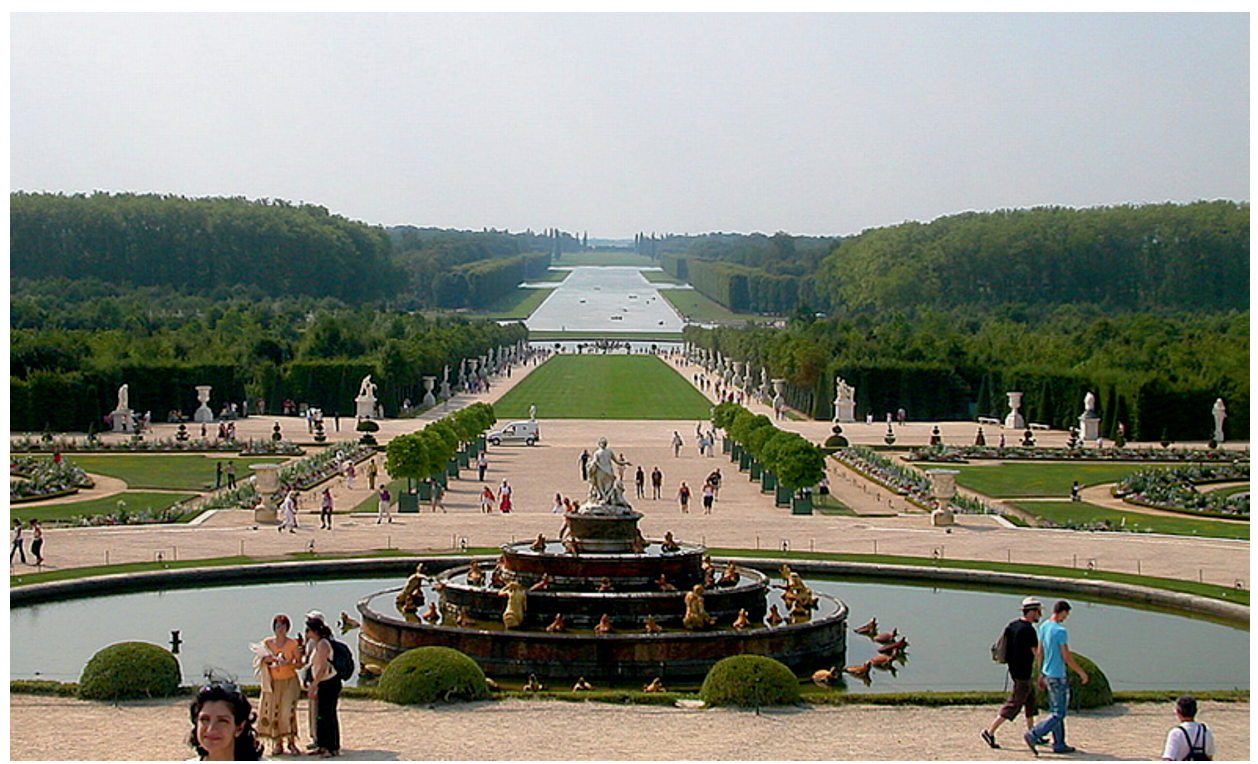

Fot. 4. Zespół ogrodowo-pałacowy Vaux le Vicomte, który powstał przed Wersalem Źródło: http://blog.bluesky.pl/zamek-vaux-le-vicomte-podroz-do-zrodel-francuskiego-baroku/ 
poprzedników, od których przejął ideę o wykorzystaniu złoconych rzeźb, nadawaniu drzewom ludzkich lub zwierzęcych kształtów. Od Włochów przejął strzyżone szpalery oraz kwatery i tarasy w kształcie prostokąta. Ogrody Wersalu stały się wzorem siedemnastowiecznych założeń ogrodowych niemal w całej Europie, w tym również w Polsce; przykładem barokowe ogrody przy pałacu Branickich w Białymstoku ${ }^{9}$ (fot. 5), czy też Wilanów ${ }^{10}$ - ulubiona letnia rezydencja króla Jana III Sobieskiego (fot. 6).

pierwszy pracowali razem, a później wspólnie przebudowywali Wersal dla Ludwika XIV. Wszyscy trzej - André Le Nôtre, Louis Le Vau i Charles Le Brun - posiadali już duże doświadczenie, ale to właśnie dzięki Vaux-le-Vicomte ich kariera osiągnęła szczyt; który niestety przyniósł niemiłe konsekwencje dla ich zleceniodawcy. 17 sierpnia 1661 roku, kiedy pałac był prawie ukończony, odbyło się w nim przyjęcie, w którym uczestniczył Ludwik XIV, jego matka Anna Austriaczka i cały dwór, który na tę okazję przyjechał z Fontainebleau do Vaux-le-Vicomte. Uroczystość swoim przepychem oczarowała gości, którzy nie tylko mogli obejrzeć zespół pałacowo-ogrodowy Fouqueta, ale byli częstowani wykwintnymi posiłkami, towarzyszyła im muzyka wykonywana przez skrzypków, specjalnie dla nich wystawiono nową sztukę Moliera Natręty, był też pokaz sztucznych ogni. Całość okazała się tak spektakularnym sukcesem, że od tego spotkania kolejnym przyjęciom w Wersalu musiały towarzyszyć analogiczne atrakcje. Niemniej chyba właśnie wtedy Ludwik XIV zadecydował o losie Fouqueta, który ośmielił się wydawać świetniejsze niż król przyjęcia oraz budować wspanialsze pałace i zakładać piękniejsze ogrody. 20 dni później Fouquet został zaaresztowany; skazany na dożywotnie więzienie zmarł w 1680 roku.

${ }^{9}$ Najpiękniejszy zabytek Białegostoku był w XVI wieku budowlą militarną - zamkiem obronnym wybudowanym przez rodzinę Wiesiołowskich. Rozkwit pałacu i ogrodów otaczających rezydencję przypada na okres panowania w Białymstoku rodu Branickich. Przebudowę zamku na pałac barokowy rozpoczął w latach 90. XVII stulecia Stefan Mikołaj Branicki, a dzieło ojca kontynuował przez kolejne pięćdziesiąt lat jego syn Jan Klemens Branicki. Metamorfoza zamku i jego otoczenia okazała się wielkim sukcesem - w konsekwencji założenie pałacowo-ogrodowe, dzieło rodu Branickich, okrzyknięto mianem Polskiego Wersalu.

${ }^{10}$ Dzieje zespołu pałacowo-ogrodowego w Wilanowie datuje się od 23 kwietnia 1677 roku, gdy wioska zwana wówczas Milanów stała się własnością panującego wówczas króla. W nawiązaniu do tradycji antycznych nazwę wioski zmieniono na Villa Nova, a następnie spolszczono ją na Wilanów. Zbudowana na początku rezydencja królewska była niewielka - nadworny architekt króla, Augustyn Wincenty Locci otrzymał bowiem zlecenie na wzniesienie jedynie parterowego dworu o układzie typowym dla architektury Rzeczypospolitej. Niemniej sukcesy militarne i wzrost znaczenia w następnych latach Jana III Sobieskiego wpłynęły na znaczne poszerzenie pierwotnego projektu. Wielką rozbudowę przeprowadzono w latach 1677-1696; po modernizacji pałac połączył w sobie elementy dworu szlacheckiego, włoskiej willi ogrodowej i francuskiego pałacu w stylu Ludwika XIV. 


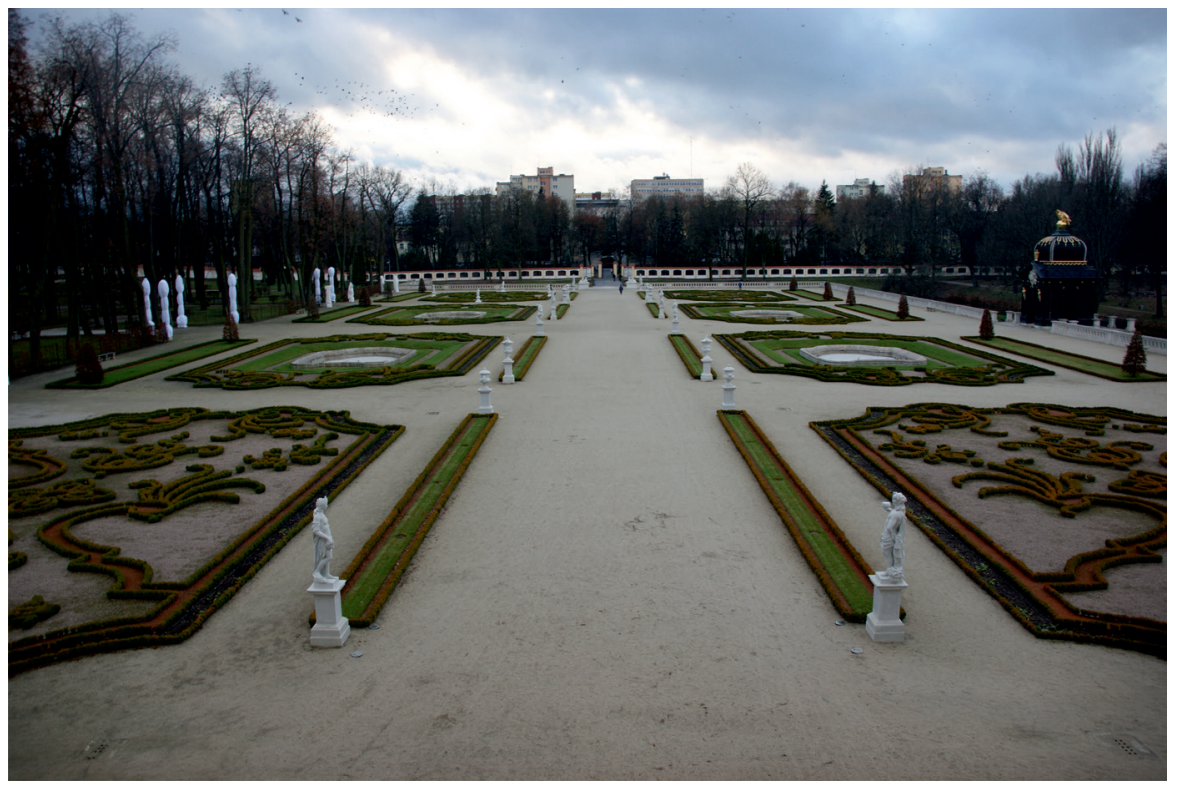

Fot. 5. Barokowy ogród Branickich w Białymstoku

fot. Krystyna Krawiec-Złotkowska

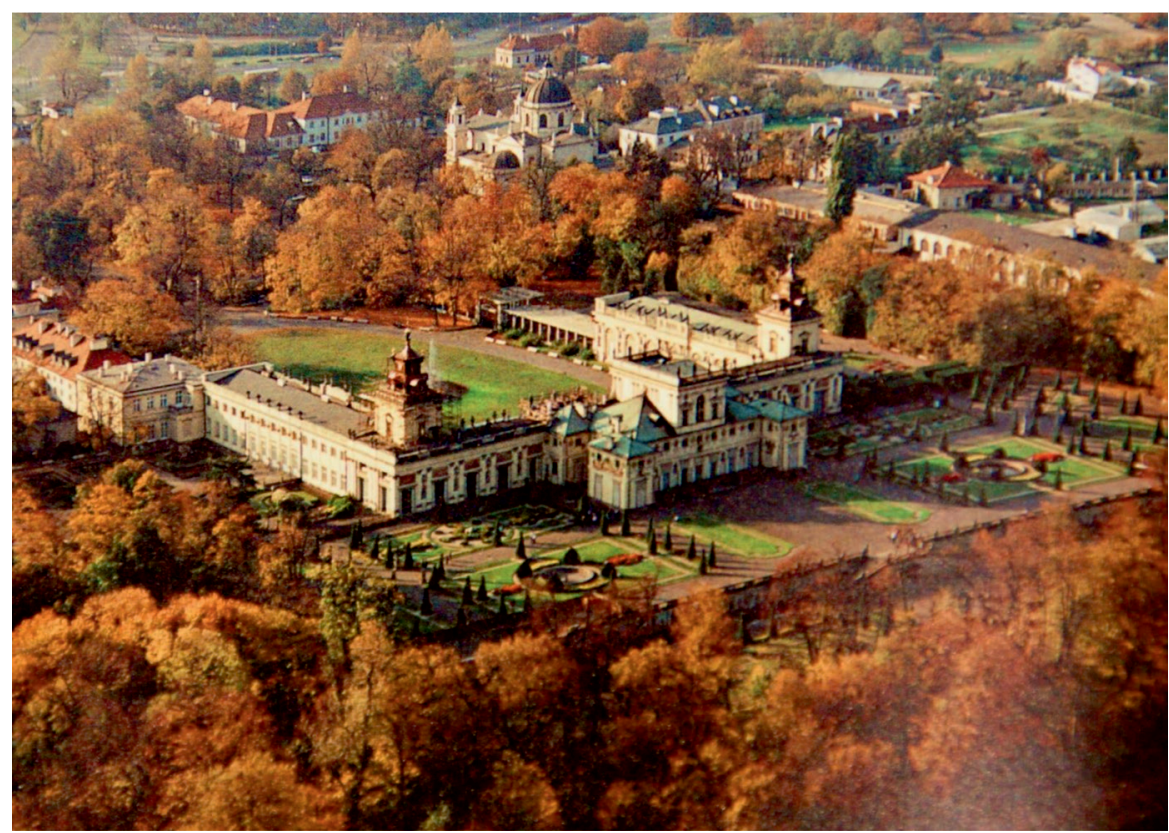

Fot. 6. Wilanów, zdjęcie lotnicze. Fragment barokowego ogrodu z pałacem, widok przed rewitalizacją

Źródło: https://pl.wikipedia.org/wiki/Ogr\%C3\%B3d_w_Wilanowie 


\section{Hortus ludi Wespazjana Kochowskiego i Kaspra Miaskowskiego}

Architektoniczny kształt zespołów pałacowo-ogrodowych oddziaływał na powstającą wówczas literaturę. Piękne wirydarze wyzwalały w gościach odwiedzających tego typu miejsca różnorodne uczucia. Przestrzeń ogrodu stawała się źródłem inspiracji do określania stanu emocjonalnego i werbalizowania uczuć, ogrodowa architektura budziła bowiem szereg skojarzeń i umożliwiała uzewnętrznienie zjawisk psychicznych. Przykładem oddziaływania „geo" na poesis mogą być wiersze Wespazjana Kochowskiego Gniazdo ojczyste do moich M.M. P.P. braciej i Rozjezne pożegnanie z ojczystym Gajem dnia 19 maja 1663 oraz Waleta włoszczonowska Kaspra Miaskowskiego.

W utworach wskazanych wyżej jako pierwsze mamy do czynienia z opisem posiadłości należących do rodziny Kochowskich herbu Nieczuja. Autor interesujących nas wierszy urodził się w 1633 roku w dziedzicznej wsi Gaju, położonej u podnóża Gór Świętokrzyskich. Maria Eustachiewicz zauważa, że: „Zarówno miejsce urodzenia (blisko sanktuarium na Świętym Krzyżu), jak i pochodzenie ze średnio zamożnej rodziny szlacheckiej stały się w jego twórczości poetyckiej znakami wartości, dowodem szczególnej Bożej łaski. Biografię Kochowskiego (w odróżnieniu od innych poetów XVII wieku) znamy dziś stosunkowo dokładnie. (...) Służba wojskowa, krąg rodzinny i przyjacielski, ważniejsze wydarzenia rodzinne znalazły wyraz w twórczości literackiej. Kochowski informował czytelników o sobie dość obficie i chętnie" (Eustachiewicz 1991, s. V).

W wierszu Gniazdo ojczyste poeta już na samym początku pisze o miejscach, które dla ich mieszkańców są najważniejsze, bo ich własne. Zwraca uwagę, że oddaleni pragną do nich powrócić. Wymienia żeglarza, który z dalekich „krajów lutyzańskich” (czyli portugalskich) „do swojej kwapi się ojczyzny”, ptaszynę, która „do gniazda swego się obziera”, Ulissesa powracającego do Itaki, Cycerona tęskniącego za Rzymem, by ostatecznie stwierdzić:

I mnie miłe Gór Świętokrzyskich knieje,

Na których wiecznie list się zielenieje,

A z między inszych wyższa pięknym brakiem

Zbawiennym Pańskim uczczona jest znakiem. (w. 17-20)

Wywyższona wśród innych góra, uczczona „Zbawiennym Pańskim (...) znakiem”, to Święty Krzyż (drugi pod względem wysokości - po Łysicy - szczyt Gór Świętokrzyskich), na którym wznosi się opactwo benedyktyńskie (współcześnie rezydują w nim księża misjonarze oblaci), będące fundacją z pierwszej połowy XII wieku, sławne ze znajdujących się w nim relikwii Krzyża Świętego. Wespazjan Kochowski podkreśla w wierszu bezpośredni związek uświęconego miejsca $\mathrm{z}$ historią jego rodu: 
Tam z dawna starzy osiadszy Sarnowie,

Jako w Hercyńskich Borach satyrowie

By lasy krzyża Pańskiego nie ćmiły,

Drzewa wycięli koło tej mogiły. (w. 21-24)

Praca przodków i ich cnota, troska o uświęconą górę i działania przyczyniające się chwale Bożej, zostały nagrodzone szczególną łaską Stwórcy (Eustachiewicz 1986, s. 154):

Nie puścił pracej tej Bóg bez zapłaty,

Że tam osiedli nie ruszeni laty;

Ta z nich po dziś dzień ma sąsiad Dąbrowa,

Lub dla dzielnice piszą się z Kochowa. (w. 25-28)

W kolejnych strofach poeta ewokuje rodzinną wieś w topice arkadyjskiej:

Z wyniosłej góry widok jest miluchny,

Pojrzeć, jak kręty idzie nurt Dobruchny,

Przy nim dziedzictwa starych Sarnów sztuki,

W których dziedziczą dotąd przez swe wnuki.

Choć mały spłacheć, kawałki, nie włości,

Leć w jednym domu wiekują z dawności. (w. 29-34)

Ojczyste gniazdo przedstawia więc Kochowski jako swoją Małą Ojczyznę, która gwarantuje szczęście i bezpieczeństwo oraz - zgodnie z tradycją sarmacką - jest wręcz nierozerwalnie związana z osobami przodków. Konwencjonalna prezentacja świata nie przeszkodziła autorowi we wprowadzeniu realistycznych elementów topograficznych, na podstawie których możemy dokładnie określić miejsce poddawane deskrypcji. Nazwa miejscowości („,piszą się z Kochowa”) i kręty „nurt Dobruchny” (rzeczki i wsi położonej w dawnym powiecie opatowskim) odsyłają do konkretnej przestrzeni u podnóża Gór Świętokrzyskich, do Gaju - rodzinnego majątku Kochowskich. To tutaj właśnie w roku 1660 osiadł Wespazjan wraz z poślubioną dwa lata wcześniej żoną Marianną Misiowską. Niestety już po trzech latach musiał zrezygnować z gospodarowania na ojcowiźnie i opuścić majątek, który po uzyskaniu pełnoletności przez jego młodszego brata Jana - zgodnie z polskim prawem zwyczajowym - przypadł właśnie jemu, jako najmłodszemu z rodu (Nowak-Dłużewski 1967, s. 238). Wespazjan wraz z rodziną przeniósł się wówczas do Goleniowa. Wydarzenie to musiało odcisnać piętno w życiu poety, o czym świadczy jego bogata ,poetycka dokumentacja”.

Wiersze ,waletowe"11, skierowane do krewnych, przyjaciół i sąsiadów Gaju, rysują ciepły obraz małej społeczności, związanej węzłami pokrewieństwa i dziedziczonej po ojcach przyjaźni. Jednocześnie Gaj przedstawiony został jako

${ }^{11}$ „Waleta” to nazwa utworu, który - jak pisze główny badacz tego typu wierszy Stefan Nieznanowski - należał do gatunków nie objętych kodyfikacją teoretyczną (Nieznanowski 1998, s. 1003-1005); pochodzi od łacińskiego słowa vale, które oznacza „żegnaj”. 
ziemiańska Arkadia, centrum skupiające wszystkie wartości szlacheckiego życia (Eustachiewicz 1991, s. VIII).

Refleksje o dziedziczonej „,przez wnuki” ojcowiźnie zamieszczone w Gnieździe ojczystym są naznaczone nostalgią. Rodzinna posiadłość jawi się jako miejsce idylliczne (Krzewińska 1979; Dąbkowska-Kujko, Krauze-Karpińska 2010) „mały spłacheć” „nie włości”. W takim kontekście Gaj położony u stóp Łysej Góry - i jednocześnie dom poety - sytuuje się w obszarze locus amoenus, który dla Kochowskiego jest już jednak niedostępny.

Żal po utraconym domu i po jego opuszczeniu wyraża poeta jeszcze wyraźniej w walecie Rozjezne pożegnanie z ojczystym Gajem dnia 19 maja 1663. Punktem wyjścia jest w tym utworze, analogicznie jak w wierszu przytoczonym wyżej, prezentacja Gaju jako Arkadii. Podmiot wiersza (Kochowski) ubolewa, że musi opuścić wieś rodzinną w maju - czyli miesiącu wiosennym, w którym natura w pełni rozkwita. Stawia retoryczne pytanie:

$$
\begin{aligned}
& \text { Czemu nie zimie, Gdy niebo drzymie } \\
& \text { I świat cerę mieni, } \\
& \text { Lubo gdy wolny Od pracy polnéj } \\
& \text { Czas bywa w jesieni? (w. 5-8) }
\end{aligned}
$$

Bohaterowi wiersza trudno się rozstać z ukochanymi kniejami, które musi porzucić bez nadziei powrotu. Zwracając się bezpośrednio do żegnanej ojcowizny, używa poetyki panegirycznej:

$$
\begin{aligned}
& \text { Ojczysty Gaju, Który w tym kraju } \\
& \text { Masz swoje pochwały, } \\
& \text { Dziedzictwo mierne, Leć panu wierne, } \\
& \text { Szpłachciu cnoty stałéj. } \\
& \text { Z dawnego wieku } \quad \text { W naszym opieku, } \\
& \text { Zawsze z jednym panem } \\
& \text { Trwasz nie przestając, Odmian nie znając, (w. 25-28) }
\end{aligned}
$$

Laudację wsi wzbogacają obrazy ukazujące piękno przyrody. Natura stanowi archetypiczny fundament dla zabaw i przyjemności, jakich można doświadczać na jej łonie:

$\begin{gathered}\text { Tu na pagórku, } \\ \text { Pierwsze krotofile; }\end{gathered}$
Ptastwo swowolne $\quad$ Powietrze wolne
Gwałcąc, cieszy mile.
Choć mała niwa,
Bujna Ceres daje,
Lecenne żniwa
Lub się ochłodzić, $\quad$ Lubo przechodzić,
Lubo na rozmowy
Do gęstej sośnie,
Możesz póść dąbrowy.




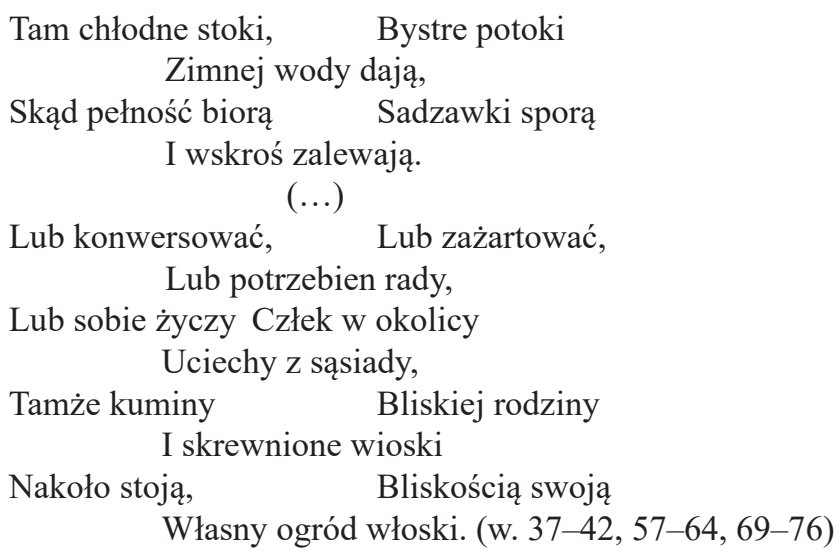

Zajęcia domowe, typowe dla staropolskiego szlachcica, przedstawione są zgodnie z konwencją idylliczną. Ziemiańskie gospodarstwo jawi się jako wspaniały hortus ludi, w którym - jak zauważa Jadwiga Kotarska - ważne są więzy krwi i sarmackie poczucie wspólnoty i familiarności (Kotarska 1980, s. 101; Kotarska 1995, passim). Bliskość Krzyża Świętego ujawniona w wierszu (obszar, gdzie można „nawiedzić miejsce Drzewem Życia sławne”) wpływa natomiast na sakralizację całej okolicy; podobnie zresztą jak zwieńczająca utwór fraza, że serce poety „będzie tęskniło” do Gaju ,jak dusza do raju”.

Podobny charakter i wymowę ma Waleta włoszczonowska Kaspra Miaskowskiego. Stefan Nieznanowski zakłada wręcz, że utwór ten był inspiracją dla Rozjeznego pożegnania... Kochowskiego (Nieznanowski 1967, passim). Podobieństwo między tymi tekstami jest jednak dosyć luźne. Kochowski, pisząc swą waletę, kierował się bowiem nie tylko osobistymi pobudkami. Zauważamy $\mathrm{w}$ jego wierszu również dumę $\mathrm{z}$ dziedzictwa przodków oraz wątki religijne. U Miaskowskiego natomiast eksponowane są przede wszystkim atuty i piękno Włoszczonowa, wsi w powiecie gostyńskim, która przez pewien okres była przez autora dzierżawiona.

Włoszczonów - per analogiam Gaju - również jest rajem na ziemi i dostarcza swoim mieszkańcom licznych rozrywek i rozkoszy. Z tego też względu opuszczającemu tę przestrzeń trudno się z nią rozstać i śpiewa pieśń pożegnalną - waletę, w której ziemiańskie zabawy i miłe jego sercu miejsca opisuje w topice elegijnej, nasyconej żalem rozstania:

Żegnam was, pola włoszczonowskiej kniei,

Gdzie się mnie wrócić nie masz i nadziei;

Żegnam cię, błotny z twymi, dworku, ściany,

Snopkiem odziany!

Żegnam was, żyzne dwa pobocz ogrody

I oba stawki hojnej pełne wody,

Gdy w nie Eolus mokrym skrzydłem żenie

$\mathrm{Z}$ pola strumienie! 
Żegnam was, sadki na wiosnę zielone,

A lecie wiśnią dojźrzałą rumione;

Daj i ty rękę, wirydarzu lichy,

Palladzie cichej!

Tu ona, szczypiąc kwiatki twe, chodziła. (w. 1-13)

Podobne, sielskie obrazy ziemiańskich posiadłości, które obok wartości estetycznych i rozrywkowych miały przecież także znaczenie utylitarne, wykreowali: Andrzej Zbylitowski w Wieśniaku (s. 168-180)12 i w Żywocie szlachcica we wsi, Hieronim Morsztyn w Ziemianinie (s. 236-237) i Szlacheckiej kondycyji (s. 238-240), Wespazjan Kochowski w Prawdziwej szczęśliwości (s. 291-293), Stanisław Słupski w Zabawach orackich (s. 190-202), Józef Domaniewski w wierszu Byt ziemiański i miejscki (s. 203-214), Kasper Twardowski w Bylicy Świętojańskiej (s. 242-244), Władysław Stanisław Jeżowski w Ekonomii abo porzadku zabaw ziemiańskich (s. 245-252), Wacław Potocki w Żywocie ziemiańskim spokojnym i szczęśliwym (s. 314-318), Jan Libicki w Żywocie ziemiańskim (s. 253-254), Mikołaj Lubieniecki w Kondycyji szlacheckiej (s. 261-263), Zbigniew Morsztyn w Votum (s. 273-281), Jan Gawiński w Żywocie ziemiańskim i dworskim (s. 284-290), czy też Jakub Kazimierz Haur w Białogłowskiego gospodarstwa powinnościach rytmami (...) opisanych (s. 303-306). Na uwagę w tym kontekście zasługują również poeci, którzy bezpośrednio nawiązywali do ody Beatus ille... Horacego lub ją parafrazowali, czyli: Stanisław Miński, który napisał Żywot ziemiański (s. 181-183), Sebastian Petrycy, autor wiersza zatytułowanego Wiejskiego obeszcia zalecenie (s. 184-186), Daniel Naborowski jako twórca Pieśni ad imitationem Horacyjuszowej ody Beatus ille qui procul negotis (s. 218-221), Samuel ze Skrzypny Twardowski i jego Ode Horatiana (s. 258-259). To oczywiście wybrane przykłady, które jednak wydają się reprezentatywne dla omawianego zjawiska.

Ogrody ziemiańskie, w których szlacheccy gospodarze nie tylko starali się odnajdywać szczęście, ale wszelkie prace związane z uprawą kwiatów, warzyw, owocowych drzew etc. traktowali jako przyjemne „krotochwile”, czyli zabawy, które można interpretować jako hortus ludi. Można rzec, że całe ziemiańskie gospodarstwa były swoistym wariantem jedynych w swoim rodzaju wirydarzy, ponieważ granice między dziardynem a sadem, przydomowymi parkami a łąkami najczęściej nie były wyraźne i zacierały się. Szlacheckie zabawy skupiały się na tym, co sarmatom było znane i bliskie, oswojone. A że najbliższa była im wielokrotnie i na różne sposoby ewokowana ,wieś spokojna, wieś wesoła”, to i „zabawy orackie" były im najbliższe. W nich właśnie upatrywali źródła rozrywki

${ }^{12}$ Wszystkie utwory wymienione w tym akapicie można znaleźć w: Staropolska poezja ziemiańska. Antologia, oprac. J.S. Gruchała i S. Grzeszczuk, Warszawa 1988. Przy kolejnych tytułach cyframi arabskimi wskazuję strony, na których znajdują się przywołane wiersze. 
i szczęścia, którego poszukiwanie ma charakter mityczny - swymi korzeniami sięga pierwotnej tęsknoty za utraconym Rajem (Delumeau 1996, passim; Kobielus 1997, passim).

Ziemiański hortus ludi, który wykreowało wielu poetów barokowych inspirujących się poezją Jana Kochanowskiego, nie wyczerpuje interesującego nas tematu. Ogrody zabaw ujawniają się bowiem nie tylko w nurcie staropolskiej poezji ziemiańskiej opiewającej uroki „wsi spokojnej, wsi wesołej”, czyli rozkosze konkretnych szlacheckich posiadłości. Wśród wierszy, zaznaczających ewokowane miejsca na mapie świata, można również wskazać takie, które opisują barokowe zabawy zupełnie innego rodzaju. Nie są to już przyjemności i rozrywki orackie, lecz zajęcia wysoce zintelektualizowane. Tego typu ogrodem zabaw służącym uczonym dysputom jest np. ogród w dobrach ujazdowskich należących do Stanisława Herakliusza Lubomirskiego.

\section{Hortus ludi Salomona polskiego}

Położony pod Warszawą pałac ujazdowski kupił Lubomirski od Teodora Denhoffa w 1674 roku. Dwa lata później magnat poślubił jego córkę Elżbietę ${ }^{13}$, która w posagu wniosła do wspólnego majątku pokaźne dobra. Ogród, który przylegał do pałacu w Ujazdowie, jak i sam pałac stały się przedmiotem podziwu ówczesnych elit (Dąbkowska-Kujko 2006, s. 8-9). Podobne wrażenia i emocje wywoływały ustronne ogrody Pałacu Kazimierzowskiego, które Lubomirski uczynił scenerią poważnych dyskursów Artaksesa i Ewandra, tytułowych postaci Rozmów (Dąbkowska-Kujko 2006, s. 7). Bohaterowie ci prowadzą erudycyjną konwersację w pięknym wirydarzu. Rozmowa jest dla nich tak pouczająca, jak i przyjemna. Jest to specyficzna odmiana barokowego hortus ludi, który swoim bywalcom stwarza sprzyjające warunki do intelektualnych, wysublimowanych rozmyślań. Wymieniane opinie, refleksje dotyczące różnych aspektów życia, czy opowiedziane zdarzenia zyskują w tej przestrzeni na znaczeniu. Sam ogród jawi się natomiast jako miejsce wyjątkowe i niepowtarzalne w nieskończonym uniwersum, a jednocześnie jako obszar, który możemy dokładnie zlokalizować. Opis wirydarza i zabaw, jakie gwarantował swoim gościom, rozpoczyna Rozmowę pierwszą:

Przy pałacu królewskim, tam kędy tylny prospekt najpiękniejszy rząd okien ku Wiśle podaje, jest jedno wesołe wyście, co chociaż do ogroda przyłączone, a przecie niejako oddalone od ogroda, miłą osobność sprawuje. To, bukszpanowym parterem i sawinami na kształt cyprysów wyniosłemi wysadzone, kamienna balustrada wokoło ogradza, że kto się na niej wesprze, ten z góry pochodzistej na

${ }^{13}$ Było to drugie małżeństwo starosty. Wcześniej, w roku 1668, wstąpił na ślubny kobierzec z Zofią Opalińską, która po siedmiu latach wspólnego życia zmarła i osierociła córkę, Elżbietę Helenę, późniejszą dziedziczkę Puław, od roku 1686 żonę Adama Mikołaja Sieniawskiego, hetmana wielkiego koronnego. 
kształt skarpy oschłe od wiślanych wód piaski daleko okiem odkrywa. Tam niejeden z przedniejszych ludzi Królestwa często, lubo sprawami zaprzątniony spoczywa, lubo też nie tylko widzeniem oko pasąc, ale i myślom pokarm dając, albo z towarzyszem rozmową bawi się, albo dworskich napaści syty krótkiej spokojności - póki mu jej albo czas, albo potrzeba, albo importun nie przerwie - łagodnie zażywa (Lubomirski 2006, s. 25).

Narrator prezentuje przestrzeń dosyć szczegółowo: mamy więc pałac królewski, z którego roztacza się widok na Wisłę (,prospekt najpiękniejszy”), informację o przejściu do tajemnej, prywatnej, położonej na uboczu głównego wirydarza części ogrodu (miejsce „niejako bokiem oddalone”), która „miłą osobność sprawuje", widzimy też bukszpanowe partery i cyprysowe boskiety, wreszcie kamienną balustradę, za którą roztacza się urocza, rozległa perspektywa na skarpę i wiślane piaski. To miejsce nie tylko zachwyca swym pięknem, lecz również uwodzi swą „spokojnością” i „myślom pokarm daje”. Intelektualne „zabawy” potwierdzają specyficzny charakter tego wirydarza, co zresztą w drugim akapicie tej Rozmowy podkreśla literalnie narrator:

To miejsce, nie prostego gminu retirata, ale gdyby mówić wprzód mogło, a potym chciało, o jako wiele powiedziałoby, co tam od chodzących i przechadzających napiło się dyskursów. Tam bowiem i interesa Królestwa nieraz namówione, i poselstwa, i instrukcyje często stanowione, i wojny, i pokoje traktowane, i rady, i namowy, i fakcyje, i ugody, i amory, i mądre rozmowy, i rzadkich nauk ciekawe powieści. Krótko mówiąc: co kilku królów i królowych niepospolitych w Europie dworów, z obojga płci osób znaczne zebranie namówić, naprawić, nagadać, mogło dotychczas rzadkiego, mądrego, skrytego, ciekawego, dowcipnego w naukach, przyrodzeniu, komplementach, żartach, powieściach politycznych i moralnych, inwencyjach, sekretach i wszelakich roztropnych zabawach, to wszystko tam zostaje schowane i złożone, że o tym miejscu bezpiecznie się może powiedzieć:

Hic locus est, quem, si verbis audacia detur,

Haud timeam magni dixisse Palatia caeli (Lubomirski 2006, s. 25).

Waloryzująca konkluzja, jaka wybrzmiewa za Owidiuszem (Metamorfozy, księga I), jest jedną wielką laudacją miejsca tak godnego, iż można o nim ,rzec śmiele, że o lepszą z samym niebem chodzi." Zestawienie wirydarza z niebiańskim pałacem można interpretować jako najwyższą pochwałę, ponieważ wszystko w nim ,zostaje schowane i złożone”, a tym samym objęte sferą tajemnicy typowej dla przestrzeni sakralnej. Obszar wpisany w strukturę przestrzenną, a więc w geograficzną i topograficzną, zyskuje status miejsca wyrastającego ponad ,geo”, bliskiego poesis.

$$
* * *
$$

Światy przedstawione w przywołanych wyżej utworach zaistniały dzięki przestrzeni geograficznej przetworzonej w umyśle poetów. Jednocześnie światy te ujmowane jako hortus ludi - poprzez oddziaływanie wykreowanego obrazu 
lirycznego na potencjalnych odbiorców tekstu tworzą nowe miejsca. W sytuacji, gdy podmiotem utworu jest ktoś, kto żegna się z ukochanym miejscem na ziemi, w jego pochwale słyszymy żal i smutek, które są konsekwencją rozstania z locus amoenus i poczucia jego straty. Jeśli jednak osoba prezentująca przestrzeń ogrodu jest szczęśliwa i spełniona, jej deskrypcja budzi tylko pozytywne emocje, wirydarz jest źródłem radości, miejscem miłym i przyjemnym, czasami wręcz sakralizowanym. Często są to obszary wyobrażone lub obrazy skonwencjonalizowane i zuniwersalizowane, inspirowane najbliższą okolicą, w której funkcjonował autor utworu. Dlatego też, badając hortus ludi, ujawniający się w literaturze w różnych wariantach, należy uwzględniać biografie autorów i ich poetyckie kreacje, zwłaszcza wówczas, gdy oni sami już w tytułach swoich utworów informują o miejscach poddawanych deskrypcji (por. Rybicka 2014, s. 373-389).

W poezji barokowej jednak nie miejsce, ale człowiek i jego dylematy były najważniejsze, dlatego też poeci tworzący w XVII wieku skupiali się przede wszystkim na ludzkiej „kondycyji” - miejsce miało określać i potwierdzać jej status. Hortus ludi w tym kontekście może mieć szerszą - niż tradycyjna - semantykę. Jako kategoria poesis z pewnością oddziaływał na sferę geograficzną i wpływał na rzeczywiste założenia ogrodowe, które miały zapewnić warunki do przyjemnego spędzania czasu. $Z$ drugiej strony poezja pozwalała dostrzec w ogrodowych kształtach i figurach coś więcej niż na pierwszy rzut oka można było zauważyć, budziła różnorodne skojarzenia oraz konotowała pozytywne lub negatywne - uzależnione od kondycji bohatera - stany ducha.

\section{Zakończenie}

Podsumowując powyższe rozważania można stwierdzić, że trajektorie geografii i literatury, ich wzajemne relacje i wpływy w przypadku poezji barokowej, zwłaszcza deskrypcji miejsc rzeczywistych, są trudne do jednoznacznego zdefiniowania. Opisywane miejsca są prezentowane w sposób konwencjonalny. Ich deskrypcja, najczęściej jest to laudacja, służy określonym celom i jest podporządkowana jakiejś idei. Barokowy hortus ludi - analizowany w perspektywie geopoetyki - na pewno istniał w świecie realnym, ale obok niego, prawdopodobnie w znacznie szerszym wymiarze, funkcjonował w mentalności siedemnastowiecznego społeczeństwa (przypomnijmy żyjącego w skomplikowanych czasach naznaczonych wojnami i piętnem Vanitas) jako kreacja szczęśliwego i przyjemnego świata, w którym myślenie, że wszystko jest zabawą, pozwalało mierzyć się z nie rozrywkową rzeczywistością.

Resumując można powiedzieć, że struktura wiersza lub prozy lokalizuje autorów tekstów w ich „własnych geografiach” i przynależnych im pozycjach. Wespazjan Kochowski i Kasper Miaskowski przyjmują perspektywę rozstania z ukochanym miejscem, Stanisław Herakliusz Lubomirski zajmuje stanowisko mentora, który opowiada o atutach wyjątkowego hortus ludi, który jest 
przestrzenią refleksji intelektualnej, miejscem sekretnym, gdzie rozmyślano nad sprawami ważnymi dla państwa i w nim podejmowano istotne decyzje, ale i terenem sprzyjającym amorom. Tym samym precyzyjnie ulokowane na mapie Gaj i Włoszczonów, czy też ogrody przy pałacu Kazimierzowskim w Warszawie, należą do różnych geografii: wyobrażonych, mitycznych (jako Arkadia), klasycyzujących, idyllicznych oraz prywatnych geografii pamięci (por. Rybicka 2014, s. 383).

\section{LITERATURA}

\section{Teksty}

Horacy, 1971, Beatus ille, qui procul negotis..., przekł. J. Birkenmajer, [w:] idem, Wybór poezji, oprac. J. Krukowski, Zakład Narodowy im. Ossolińskich, Wrocław, BN II, nr 25.

Kochanowski J., 1972, Pieśń świętojańska o Sobótce, [w:] idem, Dzieła polskie, oprac. J. Krzyżanowski, PIW, Warszawa.

Kochowski W., 1991, Pieśń XXXI z Księgi I, Gniazdo ojczyste do moich M.M. P.P. braciej, Pieśń XXIII, Rozjezne pożegnanie z ojczystym Gajem dnia 19 maja 1663 z Księgi III, [w:] idem, Utwory poetyckie. Wybór, oprac. M. Eustachiewicz, Zakład Narodowy im. Ossolińskich, Wrocław, BN I, nr 92.

Lubomirski S.H., 2006, Rozmowy Artaksesa i Ewandra, wyd. J. Dąbkowska-Kujko, IBL, BPS, t. 32, Warszawa.

Miaskowski K., 1988, Waleta włoszczonowska, [w:] Staropolska poezja ziemiańska. Antologia, oprac. J.S. Gruchała i S. Grzeszczuk, PIW, Warszawa.

Wergiliusz, 1953, Bukoliki i georgiki. Wybór, przeł. Z. Abramowiczówna, Zakład Narodowy im. Ossolińskich, Wrocław, BN II, nr 83.

\section{Opracowania}

Bachmann-Medick D., 2012, Cultural turns. Nowe kierunki w naukach o kulturze, przeł. K. Krzemieniowa, Oficyna Naukowa, Warszawa.

Balbus S., 1995, Granice poetyki i kompetencje literatury, [w:] Bolecki W., Tomasik W. (red.), Poetyka bez granic, IBL, Warszawa.

Ciołek G., 2009, Ogrody polskie, Warszawa.

Collot M., 2008, De la geopoétique, [w:] L'habiter dans sa poétigue prèmiere, sous la direction de A. Berque, A. de Biase, Ph. Bonnin, Paris.

Czapiga M., 2013, Labirynt: inicjacja, podróż, zbłądzenie. Figura ludzkiego losu w kulturze europejskiej, Wydawnictwo Uniwersytetu Wrocławskiego, Wrocław.

Dąbkowska-Kujko J., 2006, Wprowadzenie do lektury, [w:] Lubomirski S.H., Rozmowy Artaksesa i Ewandra, wyd. J. Dąbkowska-Kujko, IBL, BPS, t. 32, Warszawa.

Dąbkowska-Kujko J., Krauze-Karpińska J. (red.), 2010, Staropolskie Arkadie, IBL PAN, Warszawa.

Delumeau J., 1994, Grzech i strach. Poczucie winy w kulturze Zachodu XIII-XVIII w., przeł. A. Szymanowski, Warszawa.

Delumeau J., 1996, Historia raju. Ogród rozkoszy, przeł. E. Bąkowska, PIW, Warszawa. 
Dziuban Z., 2008, Atopia - poza miejscem i nie-miejscem, [w:] Wilkoszewska K., Petri J. (red.), Czas przestrzeni, Universitas, Kraków.

Eustachiewicz M., 1986, Liryka Wespazjana Kochowskiego, [w:] Eustachiewicz M., Majewski W., Nad lirykami Wespazjana Kochowskiego, IBL, Zakład Narodowy im. Ossolińskich, Wrocław.

Eustachiewicz M., 1991, Wstęp, [w:] Kochowski W., Utwory poetyckie. Wybór, oprac. M. Eustachiewicz, Zakład Narodowy im. Ossolińskich, Wrocław, BN I, nr 92.

Fischer-Lichte E., 2008, Estetyka performatywności, przeł. M. Borowski, M. Sugiera, Księgarnia Akademicka, Kraków.

Gruchała J.S., Grzeszczuk S. (red.), 1988, Staropolska poezja ziemiańska. Antologia, Państwowy Instytut Wydawniczy, Warszawa.

Ihnatowicz E., 1997, Kiedy kamienica jest a kiedy nie jest domem polskim, [w:] Dąbek-Wirgowa T., Makowiecki A.Z. (red.), Obraz domu w kulturach słowiańskich, Wydawnictwo Uniwersytetu Warszawskiego, Wydział Polonistyki, Warszawa.

Impelluso L., 2009, Ogrody i labirynty. Leksykon - historia, sztuka, ikonografia, Arkady, Warszawa.

Karpiński A., 1983, Staropolska poezja ideałów ziemiańskich. Próba przekroju, IBL, Zakład Narodowy im. Ossolińskich, Wrocław.

Kobielus S., 1997, Człowiek i ogród rajski w kulturze religijnej średniowiecza, Instytut Wydawniczy PAX, Warszawa.

Kotarska J., 1980, Erotyk staropolski. Inspiracje $i$ odmiany, IBL, Zakład Narodowy im. Ossolińskich, Wrocław.

Kotarska J., 1995, Ad caelestem adspirat patriam. Problem dualizmu natury ludzkiej w poezji polskiego baroku, [w:] Nowicka-Jeżowa A., Hanusiewicz M., Karpiński A. (red.), Literatura polskiego baroku. W kręgu idei, Wydawnictwo Katolickiego Uniwersytetu Lubelskiego, Lublin.

Krawiec-Złotkowska K., 2007, ,Gdziekolwiek pojźrysz, wszędzie na świat pojźreć mile..." Lasy, gaje, sady, taki, pola i ogrody jako naturalne komponenty przestrzenne staropolskiego orbis terrarum, [w:] Łysiak W. (red.), Las w kulturze polskiej V, Wydawnictwo „Eco”, Poznań.

Krawiec-Złotkowska K., 2008a, W ogrodach zamkowych księżnej Erdmuty $i$ księżnej Anny de Croy - ostatniej Gryfitki, [w:] Krawiec-Złotkowska K. (red. i wstęp), Rzeczpospolita domów I. Zamki, dworki i pałace, Wydawnictwo Naukowe Akademii Pomorskiej, Słupsk.

Krawiec-Złotkowska K., 2008b, Ogrody w poezji Wacława Potockiego na tle kultury dawnej Europy, [w:] Gazda G., Gołąb M. (red.), Przestrzeń ogrodu-przestrzeń kultu$r y$, Universitas, Kraków.

Krawiec-Złotkowska K., 2008c, Gardens in Wacław Potocki’s Poetry against the Background of the Culture of Ancient Europe, [w:] Space of a Garden - Space of Culture, Cambridge Scholars Publishing.

Krawiec-Złotkowska K., 2009, Ogród rajski w „Emblemata” Zbigniewa Morsztyna, [w:] Abramowicz Z., Ławski J. (red.), Chrześcijańskie dziedzictwo duchowe narodów słowiańskich, Seria II: Wokót kultur Śródziemnomorza, t. 1: Literatura i słowo, Wydawnictwo Trans Humana, Białystok. 
Krzewińska A., 1979, Sielanka staropolska. Jej początki, tradycje i główne kierunki rozwoju, PWN, Warszawa-Poznań-Toruń.

Kuźma 1995, O poetyce negatywnej. Od poetyki do poetologii, od poetologii do metapoetyki, [w:] Bolecki W., Tomasik W. (red.), Poetyka bez granic. Z Dziejów Form Artystycznych w Literaturze Polskiej, Warszawa.

Latour B., 2010, Splatając na nowo, to, co spoteczne. Wprowadzenie do teorii aktorasieci, wstęp K. Abriszewski, przeł. A. Derra, Universitas, Kraków.

Majdecki L., 2009, Historia ogrodów, t. 1: Od starożytności po barok, t. 2: Od XVIII wieku do wspótczesności, zmiany i uzupełnienia A. Majdecka-Strzeżek, PWN, Warszawa.

Mitchell W.J.T., 2002, Introduction, [w:] Mitchell W.J.T. (red.), Landscape and Power, Chicago, London.

Moretti F., 1998, Atlas of the European Novel 1880-1900, London-New York.

Nieznanowski S., 1967, Staropolska elegia pożegnalna, „Sprawozdania z Prac Naukowych Wydziału I PAN", 2.

Nieznanowski S., 1998, Waleta, [w:] Michałowska T., Otwinowska B., Sarnowska-Temeriusz E. (red.), Stownik literatury staropolskiej, IBL, Zakład Narodowy im. Ossolińskich, Wrocław.

Nowak-Dłużewski J., 1967, Wespazjan Kochowski. Pierwszy regionalny poeta kielecki, [w:] Z historii polskiej literatury i kultury, Instytut Wydawniczy PAX, Warszawa.

Rybicka E., 2014, Geopoetyka. Przestrzeń i miejsce we wspótczesnych teoriach i praktykach literackich, Universitas, Kraków.

Sack R.D., 1997, Homo Geographicus. A Framework for Action, Awareness and Moral Concerns, Baltimore, London.

Schlögel K., 2009, W przestrzeni czas czytamy. O historii cywilizacji i geopolityce, przekł. I. Drozdowska, Ł. Musiał, Wydawnictwo Poznańskie, Poznań.

Skwarczyńska S., 1937, Regionalizm a główne kierunki teorii literatury, „Prace Polonistyczne", Seria I.

Soja E.W., 2009, Taking Space Personally, [w:] Warf B., Arias S. (red.), The Spatial Turn. Interdisciplinary Perspectives, London-New York.

Warf B., Arias S., 2009, Introduction: the Reinsertion of Space into the Social Sciences and Humanities, [w:] Warf B., Arias S. (red.), The Spatial Turn. Interdisciplinary Perspectives, London-New York.

Zaleski M., 2007, Echa idylli w literaturze polskiej doby nowoczesności i późnej nowoczesności, Universitas, Kraków.

\section{BAROQUE HORTUS LUDI IN THE PERSPECTIVE OF GEOPOETICS (ON CHOSEN LITERARY EXAMPLES)}

Abstract The article shows a baroque hortus ludi (the garden of entertainment) in the perspective of geopoetics. The subject of explorations are chosen works of seventeenth century's poets in the base of which there was considered this studied phenomenon. There was demonstrated to what extent real places could inspire authors who were writing about noble or baronial patios and on the other hand, there was made a try of designation how the literary creation builds subjected places for a potential receiver (reader). As a result of 
analysis it was alleged that descriptions of baroque hortus ludi-creations of places processed in poet's mind, characterised by aspect of being painterly, which can inspire not only landscape architects, but also painters and other artists.

In the article there was also considered a genesis of baroque gardens of entertainment and distinctive features of park-garden assumptions, starting with medieval times to baroque. Hortus ludi present in poetry of seventeenth century was shown in new, geopoethical conceptualization.

Keywords Baroque, poetry, garden, hortus ludi, Arcadia, topos, space, geopoetry, geographical-literary interactions.

Dr Krystyna Krawiec-Złotkowska Zakład Historii Literatury, Instytut Polonistyki Wydział Filologiczno-Historyczny Akademia Pomorska w Słupsku 